\title{
Organizing the Challenges Faced by Municipalities while Formulating Climate Change Adaptation Plans
}

\author{
Asako Iwami ${ }^{1, *}$, Takanori Matsui ${ }^{2}{ }^{(\mathbb{D}}$, Michinori Kimura $^{3}$, Kenshi Baba ${ }^{4} \mathbb{D}$ and Mitsuru Tanaka ${ }^{5}$ \\ 1 Center for Regional Research, Hosei University, 2-17-1 Fujimi, Chiyoda-ku, Tokyo 102-8160, Japan \\ 2 Graduate School of Engineering, Osaka University, 2-1 Yamadaoka, Suita, Osaka 565-0871, Japan; \\ matsui@see.eng.osaka-u.ac.jp \\ 3 Department of Integrated Analysis, Lake Biwa Environmental Research Institute, 5-34 Yanagasaki, Otsu, \\ Shiga 520-0022, Japan; kimura-m@lberi.jp \\ 4 Faculty of Environmental Studies, Tokyo City University, 3-3-1 Ushikubo-nishi, Tsuzuki-ku, yokohama, \\ Kanagawa 224-8551, Japan; kbaba@tcu.ac.jp \\ 5 Faculty of Social Sciences, Hosei University, 4342 Aihara, Machida, Tokyo 194-0298, Japan; \\ mtanaka@hosei.ac.jp \\ * Correspondence: asako.iwami.37@hosei.ac.jp
}

Received: 15 January 2020; Accepted: 5 February 2020; Published: 7 February 2020

check for updates

\begin{abstract}
As the effects of climate change increase in severity, organizations across the world are attempting to measures to mitigate these effects. In accordance with the Paris Agreement of November 2015 , wherein participating nations agreed to restrict the increase in global temperature below $2{ }^{\circ} \mathrm{C}$, Japan has formulated guidelines on creating adaptation plans that can be implemented by local governments. A Climate Change Adaptive Information Platform was also launched to promote understanding and cooperation by sharing information on climate risks. However, the literature on this topic lacks information related to the organization of requirements and challenges faced by municipal administrative officials that formulate adaptation plans. To address these issues, we examined the four municipal forums hosted at Hosei University to encourage administrative needs for new technological ideas in areas such as climate modeling and impact assessment. We used text mining on the transcripts of the various workshops conducted in these forums and attempted to understand the changes in discussions and to extract issues related to the formulation process. The results showed that various topics, such as creating adaptation promotion systems, assessing the impacts of climate change, formulating adaptation plans, communicating with related organizations and stakeholders, developing human resources, and capacity building, were discussed, and a need for information, procedures, and assistance was identified for the formulation of feasible adaptation plans. This study is expected to provide a useful reference to stakeholders involved in framing adaptation plans to mitigate the effects of climate changes, particularly at the municipal level.
\end{abstract}

Keywords: climate change; local government; impact assessment; adaptation plans; text mining

\section{Introduction}

The Paris Agreement of November 2015 established a goal of restricting the increase in temperatures since the Industrial Revolution to less than $2{ }^{\circ} \mathrm{C}$ and provided a clear direction for implementing aggressive adaptation provisions [1]. In Japan, around this time, the Cabinet approved the "National Plan for Adaptation to the Impacts of Climate Change." In August 2016, the Ministry of the Environment laid out clear procedures, issues, and guidelines to consider when making climate change impact assessments and formulating adaptation plans in its "Guidelines on Formulating Climate Change Adaptation Plans for Local Governments" (guidelines) [2]. A Climate Change Adaptive Information 
Platform (A-PLAT) was created as a core initiative to promote understanding and cooperation by sharing and providing information on climate risks and other issues [3]. In December 2018, the Climate Change Adaptation Law was enacted. In particular, this law requires local governments to work toward formulating a "local climate change adaptation plan" (adaptation plan) based on local conditions and create systems to perform the functions of a "local climate change adaptation center" (local adaptation center) to serve as a base for collecting and supplying information on adaptation at the local level [4].

In addition, the Ministry of Education, Culture, Sports, Science, and Technology launched the Social Implementation Program on Climate Change Adaptation Technology (SI-CAT) [5] in the fiscal year 2015. This program aims to develop technologies for reliable short-term climate change forecasts that can be widely applied to examine and formulate climate change adaptation provisions by municipalities all over Japan, assess the effectiveness of the adaptation provisions that have been introduced, and support the introduction of adaptation provisions based on local characteristics to address extreme weather phenomena, which are expected to become more frequent going forward. In the seven nationwide model municipalities, technological development organizations, such as the National Institute for Environmental Studies (NIES) and the Japan Agency for Marine-Earth Science and Technology (JAMSTEC) are working toward develop technologies for climate change forecast and impact assessments. Simultaneously, social implementation organizations, such as the Japan Science and Technology Agency (JST) and Hosei University, are working on areas such as supporting the introduction of adaptation provisions.

As the effects of climate change will vary from region to region, adaptation provisions must be considered and implemented based on the local characteristics and impacts. Previous studies on introducing adaptation provisions at the local level conducted interviews and questionnaire surveys in municipal governments. These have highlighted the need to bridge the potential gaps between policy makers, experts, and citizens regarding the impacts and risks of climate change [6]; issues such as the uncertainties associated with future predictions and impact forecasts; the lack of funds and support from the national government; and the difficulties involved in interdepartmental coordination and cooperation $[7,8]$. However, we could not find any attempts to organize the requirements and challenges faced by the municipal administrative officials in charge of formulating adaptation plans, which were based on the discussions between the municipal officials who make policy and the experts who provide scientific findings.

Hosei University, which plays the role of a social implementation organization at SI-CAT, has hosted four municipal adaptation forums to encourage administrative needs for new technological ideas in areas such as climate modeling and impact assessment and ensure that the solutions to the requirements are co-designed through collaboration between the experts who nurture these technological seeds and municipal officials [9]. The authors identified the themes discussed in the workshops (WSs) of the first and second forums by analyzing transcripts from the WSs (see Tables 3 and 4 below). We discovered differences in the tendencies of statements and their structure used by researchers and municipal officials and identified problems in applying long-term forecast data for setting targets and studying short-term administrative plans when adaptation provisions were being examined. Additionally, we recognized the various needs related to easy-to-understand information that can be provided to related departments and citizens and frameworks that can supply continuously updated forecast data $[10,11]$. At this stage, however, there has been no consideration of the process of formulating adaptation plans or focus on how discussions have varied due to changes in social conditions, such as the founding of A-PLAT and enactment of the Climate Change Adaptation Law.

Therefore, in this study, our objective was to organize the themes discussed in the WSs at the four forums to determine the steps of the corresponding adaptation planning process, understand how the WS discussions changed over time, and extract issues related to the formulation process. 


\section{Methods}

\subsection{Overview of the Municipal Adaptation Forums}

Tables 1 and 2 provides an overview of the municipal adaptation forums that have been held so far. As presented in the table, forums on themes related to social conditions were held annually every August from 2016 to 2019. The participants of these forums consisted of 76, 109, 131, and 127 representatives of national government entities (such as the Ministry of Education, Culture, Sports, Science, and Technology and the Ministry of the Environment), municipal governments, local environmental research institutes, and organizations associated with SI-CAT, respectively. The first portion of each forum addressed topics, such as the latest research trends in technological development and social implementation organizations, the status of adaptation plans in municipalities nationwide, and the initiatives taken by leading municipalities. The second portion consisted of WSs where municipal officials could directly exchange views with researchers specializing in climate models and impact assessments.

Table 1. Overview of municipal adaptation forums 1-4.

\begin{tabular}{|c|c|c|c|c|}
\hline & Forum No. 1 & Forum No. 2 & Forum No. 3 & Forum No. 4 \\
\hline Date & August 31, 2016 (Wed) & August 30, 2017 (Wed) & August 28, 2018(Tue) & August 28, 2019 (Wed) \\
\hline Location & \multicolumn{4}{|c|}{ Hosei University, Ichigaya Campus } \\
\hline Themes & $\begin{array}{l}\text { Identifying the } \\
\text { potential needs of } \\
\text { municipalities } \\
\text { Challenges related } \\
\text { to specifying and } \\
\text { implementing } \\
\text { adaptation } \\
\text { provisions and } \\
\text { studying the lateral } \\
\text { deployment of } \\
\text { socialimplementation }\end{array}$ & $\begin{array}{l}\text { - } \\
\text { Providing climate } \\
\text { change data for } \\
\text { formulating local } \\
\text { adaptation provisions } \\
\text { Using } \\
\text { administrative } \\
\text { practices }\end{array}$ & $\begin{array}{l}\text { Verifying and } \\
\text { clarifying issues } \\
\text { related to the } \\
\text { process of } \\
\text { implementing } \\
\text { climate science } \\
\text { technology and } \\
\text { data in municipal } \\
\text { governments }\end{array}$ & $\begin{array}{l}\text { Verifying and } \\
\text { clarifying issues } \\
\text { related to the } \\
\text { process } \\
\text { implementing of } \\
\text { climate science } \\
\text { technology and } \\
\text { data in municipal } \\
\text { governments }\end{array}$ \\
\hline $\begin{array}{l}\text { Affiliation of } \\
\text { participants }\end{array}$ & $\begin{array}{l}\text { Ministry of Education, } \\
\text { Culture, Sports, Science, } \\
\text { and Technology; } \\
\text { Ministry of the } \\
\text { Environment. } \\
\text { Municipal governments } \\
\text { nationwide interested in } \\
\text { adaptation provisions, } \\
\text { local environmental } \\
\text { research institutes, } \\
\text { organizations associated } \\
\text { with SI-CAT, others. } \\
\text { Total: } 76 \text { people }\end{array}$ & $\begin{array}{l}\text { Ministry of Education, } \\
\text { Culture, Sports, } \\
\text { Science, and } \\
\text { Technology; Ministry } \\
\text { of the Environment; } \\
\text { Ministry of Land, } \\
\text { Infrastructure, } \\
\text { Transport, and } \\
\text { Tourism. } \\
\text { Municipal } \\
\text { governments } \\
\text { nationwide interested } \\
\text { in adaptation } \\
\text { provisions, local } \\
\text { environmental } \\
\text { research institutes, } \\
\text { organizations } \\
\text { associated with SI-CAT, } \\
\text { others. } \\
\text { Total: } 109 \text { people }\end{array}$ & $\begin{array}{l}\text { Ministry of Education, } \\
\text { Culture, Sports, } \\
\text { Science, and } \\
\text { Technology; Ministry } \\
\text { of the Environment; } \\
\text { Ministry of Land, } \\
\text { Infrastructure, } \\
\text { Transport, and } \\
\text { Tourism; Ministry of } \\
\text { Agriculture, Forestry, } \\
\text { and Fisheries; Japan } \\
\text { Meteorological Agency. } \\
\text { Municipal } \\
\text { governments } \\
\text { nationwide interested } \\
\text { in adaptation } \\
\text { provisions, local } \\
\text { environmental } \\
\text { research institutes, } \\
\text { organizations } \\
\text { associated with SI-CAT, } \\
\text { others. } \\
\text { Total: 131 people }\end{array}$ & $\begin{array}{l}\text { Ministry of Education, } \\
\text { Culture, Sports, Science, } \\
\text { and Technology; } \\
\text { Ministry of the } \\
\text { Environment; Ministry } \\
\text { of Land, Infrastructure, } \\
\text { Transport, and Tourism; } \\
\text { Ministry of Agriculture, } \\
\text { Forestry, and Fisheries; } \\
\text { Japan Meteorological } \\
\text { Agency. } \\
\text { Municipal governments } \\
\text { nationwide interested in } \\
\text { adaptation provisions, } \\
\text { local environmental } \\
\text { research institutes, } \\
\text { organizations associated } \\
\text { with SI-CAT, others. } \\
\text { Total: } 127 \text { people }\end{array}$ \\
\hline
\end{tabular}


Table 2. Overview of municipal adaptation forums 1-4.

\begin{tabular}{|c|c|c|c|c|}
\hline & Forum No. 1 & Forum No. 2 & Forum No. 3 & Forum No. 4 \\
\hline Agenda & 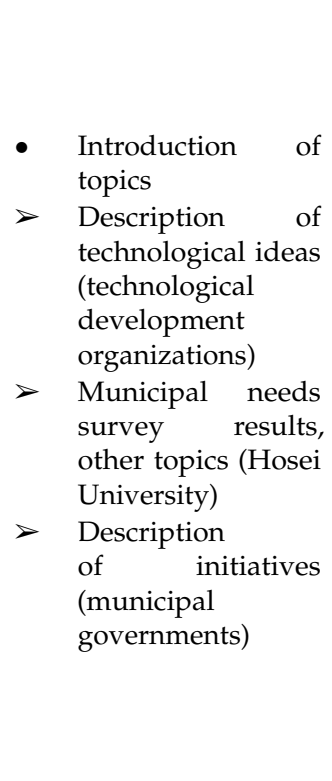 & $\begin{array}{l}\text { - } \begin{array}{l}\text { Introduction } \\
\text { of topics }\end{array} \\
\text { Description of } \\
\text { technological } \\
\text { ideas } \\
\text { (technological } \\
\text { development } \\
\text { organizations) } \\
\text { Adaptation plan } \\
\text { formulation } \\
\text { status, other } \\
\text { topics (Hosei } \\
\text { University) } \\
\text { Local adaptation } \\
\text { consortium } \\
\text { projects } \\
\text { (Ministry of } \\
\text { the Environment) } \\
\text { Description } \\
\text { of initiatives } \\
\text { (municipal } \\
\text { governments) }\end{array}$ & 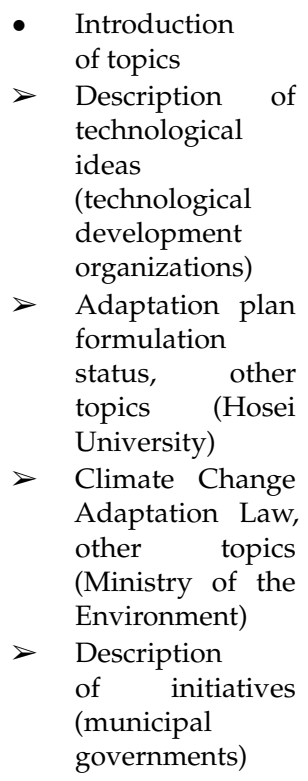 & $\begin{array}{l}\text { - Introduction of topics } \\
\text { Description of of } \\
\text { technological ideas } \\
\text { (technological } \\
\text { development } \\
\text { organizations) } \\
\text { Adaptation plan } \\
\text { formulation status, } \\
\text { other topics (Hosei } \\
\text { University) } \\
\text { Description of } \\
\text { initiatives at model } \\
\text { municipalities } \\
\text { (municipal } \\
\text { governments) }\end{array}$ \\
\hline & $\begin{array}{l}- \text { Workshops } \\
\text { Technological } \\
\text { development } \\
\text { to help local } \\
\text { governments create } \\
\text { adaptation plans }\end{array}$ & 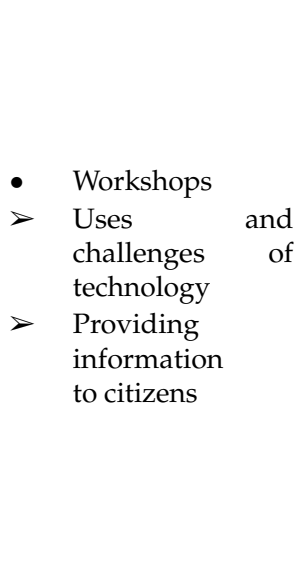 & $\begin{array}{l}\text { - Workshops } \\
\text { Experience of } \\
\text { SI-CAT model } \\
\text { municipalities } \\
\text { and others } \\
\text { in social } \\
\text { implementation, } \\
\text { case examples } \\
\text { Mutual } \\
\text { understanding of } \\
\text { current impacts, } \\
\text { needs, and ideas } \\
\text { Local climate } \\
\text { change } \\
\text { adaptation } \\
\text { centers }\end{array}$ & $\begin{array}{l}\text { Workshops } \\
\text { Challenges related } \\
\text { to forecasting and } \\
\text { evaluating climate } \\
\text { change impacts } \\
>\text { Challenges in setting } \\
\text { adaptation goals and } \\
\text { managing progress } \\
>\text { Challenges related } \\
\text { to establishing } \\
\text { and equipping } \\
\text { regional adaptation } \\
\text { centers, division of } \\
\text { roles between the } \\
\text { national and local } \\
\text { governments }\end{array}$ \\
\hline
\end{tabular}

For the WSs in the second portion, three groups were formed on "adaptation planning in general" and one group each in the fields of "agriculture," "disaster preparation," and "heat." Participants were assigned to groups by taking their field of specialty and affiliation into account and ensuring that each group included researchers from technological development organizations and local environmental research institutes in addition to municipal officials. The themes of the WSs, like the forums, examined the state of society and technological developments. The first forum was held on "technological developments to help local governments create adaptation plans," the second was on "technological uses and challenges, and providing information to citizens," the third discussed "mutual understanding of today's impacts, needs, and ideas, and local climate change adaptation centers," and the fourth explored "challenges in setting adaptation goals and managing progress, and division of roles between the national and local governments."

\subsection{Analysis Framework}

As described above, the authors previously identified themes discussed in the first and second municipal adaptation forums by text mining the transcripts of the WSs on "adaptation planning in 
general" (see Tables 3 and 4). In the table, each theme is labeled as "municipal adaptation forum No. theme No. at this forum," and examples of remarks under each theme are given. The same applies to Tables 5 and 6 below.

Table 3. Themes discussed in the workshops (WSs) at the first municipal adaptation forums [10].

\begin{tabular}{|c|c|c|}
\hline Label & Themes & Example Statements \\
\hline $1-1$ & $\begin{array}{l}\text { Accuracy of research } \\
\text { results }\end{array}$ & $\begin{array}{l}\text { "I am interested in how the results of impact assessments will be } \\
\text { implemented and whether they are really useful." "What level of } \\
\text { accuracy do municipal governments really need?" }\end{array}$ \\
\hline $1-2$ & Data sources & $\begin{array}{l}\text { "The SI-CAT app is approved by the Ministry of Education and A-PLAT } \\
\text { is approved by the Ministry of the Environment." "It is good for } \\
\text { ministries and agencies to have a shared understanding; for instance, a } \\
\text { willingness to use the results of Ministry of Education projects." }\end{array}$ \\
\hline $1-3$ & Mainstream adaptation & $\begin{array}{l}\text { "It is important for all kinds of people to think about adaptation } \\
\text { provisions and the effects of global warming, and for adaptation } \\
\text { provisions to become mainstream." "It is difficult to know how to best } \\
\text { incorporate the perspectives of adaptation provisions when changing } \\
\text { standards or promoting countermeasures." }\end{array}$ \\
\hline $1-4$ & Simple tools & $\begin{array}{l}\text { "Some people say we should develop a set of easy-to-use tools." "It } \\
\text { might be useful to have tools that are as easy-to-use and roughly } \\
\text { accurate as weather forecasts." }\end{array}$ \\
\hline $1-5$ & $\begin{array}{c}\text { Explanations to other } \\
\text { departments }\end{array}$ & $\begin{array}{l}\text { "The need for adaptation provisions must be explained objectively to } \\
\text { the departments involved." "We need to explain the need for } \\
\text { adaptation provisions to finance departments to secure funding but it is } \\
\text { difficult to properly explain the evidence to them." }\end{array}$ \\
\hline $1-6$ & $\begin{array}{c}\text { National government } \\
\text { authorization }\end{array}$ & $\begin{array}{l}\text { "If you are not an expert, you need to have official approval when you } \\
\text { are asked to explain something." "I want official approvals of impact } \\
\text { assessments to be based on the opinions of researchers, not just the } \\
\text { judgments of municipal governments." }\end{array}$ \\
\hline $1-7$ & Reviewing priorities & $\begin{array}{l}\text { "One challenge is how to determine the priority of initiatives amid a } \\
\text { huge amount of diverse information." "Is there a relationship between a } \\
\text { thing's priority and the probability it will occur?" }\end{array}$ \\
\hline $1-8$ & $\begin{array}{l}\text { Personnel changes and } \\
\text { collaborating with other } \\
\text { departments }\end{array}$ & $\begin{array}{l}\text { "Personnel changes present challenges in terms of having a shared } \\
\text { knowledge and awareness of the adaptation provisions." "Although } \\
\text { transferring staff who understand adaptation provisions to other } \\
\text { departments can be beneficial because it spreads knowledge about } \\
\text { provisions, we are not at that stage yet." }\end{array}$ \\
\hline $1-9$ & Accuracy needs & $\begin{array}{l}\text { "At this stage, I would rather understand the general directions than } \\
\text { have detailed information." "Information based on local terrain and } \\
\text { characteristics is more useful than rainfall forecasts." }\end{array}$ \\
\hline $1-10$ & $\begin{array}{l}\text { Easy-to-understand } \\
\text { information and } \\
\text { reliability }\end{array}$ & $\begin{array}{l}\text { "Everyone who sees confidence and reliability assessments should be } \\
\text { able to understand them." "When explaining risks to residents, the } \\
\text { information needs to be accurate and easy to understand." }\end{array}$ \\
\hline $1-11$ & Top-down information & $\begin{array}{l}\text { "Is it better to provide information on impacts that are likely to occur in } \\
\text { a top-down manner or for necessary information to be requested in a } \\
\text { bottom-up manner?" "I am grateful when information is provided from } \\
\text { the top down." }\end{array}$ \\
\hline $1-12$ & $\begin{array}{l}\text { Necessary forecast } \\
\text { information }\end{array}$ & $\begin{array}{l}\text { "If precipitation and temperature forecasts are known at the municipal } \\
\text { and community levels, this information can be useful in formulating } \\
\text { disaster preparation and mitigation plans." "If municipal governments } \\
\text { and technological development organizations communicate on the } \\
\text { information required for impact assessments, such as temperature, } \\
\text { precipitation, and rainfall intensity, it will help ensure that needs align } \\
\text { with ideas." }\end{array}$ \\
\hline $1-13$ & $\begin{array}{c}\text { Studying specific } \\
\text { adaptation provisions }\end{array}$ & $\begin{array}{l}\text { "As flooding is expected to become more common, some municipalities } \\
\text { are promoting river basin flood control." "In the real world, specific } \\
\text { impacts should come with their countermeasures as a set, along with } \\
\text { the data to justify them." }\end{array}$ \\
\hline
\end{tabular}


Table 4. Themes discussed in the WSs at the second municipal adaptation forums [11].

\begin{tabular}{|c|c|c|}
\hline Label & Themes & Example Statements \\
\hline $2-1$ & Setting numerical goals & $\begin{array}{l}\text { "It is often impossible to set numerical goals or indices." "We are } \\
\text { focusing on setting indices for initiatives and if the departments } \\
\text { involved agree, these will be used as the yardstick for promoting } \\
\text { adaptation provisions." }\end{array}$ \\
\hline $2-2$ & $\begin{array}{l}\text { Global warming } \\
\text { countermeasures }\end{array}$ & $\begin{array}{l}\text { "Adaptation provisions are not well known among citizens and other } \\
\text { governmental departments." "When providing information to citizens } \\
\text { through public awareness campaigns, visual information is effective } \\
\text { and could be used as an adaptation provision for disaster preparation." }\end{array}$ \\
\hline $2-3$ & $\begin{array}{l}\text { Examining the contents } \\
\text { of plans }\end{array}$ & $\begin{array}{l}\text { "How should provisions in a wide range of fields be packaged?" "We set } \\
\text { up a study group among related departments to consider the contents of } \\
\text { the plan, and invited staff from leading municipalities to give lectures." }\end{array}$ \\
\hline $2-4$ & Revising plans & $\begin{array}{l}\text { "We ask related departments to identify the impacts and } \\
\text { countermeasures to formulate and review policies." "The staff in charge } \\
\text { gain knowledge from gathering information and creating the plan but } \\
\text { when staff change, this information is not passed on." }\end{array}$ \\
\hline $2-5$ & $\begin{array}{l}\text { Providing information to } \\
\text { citizens }\end{array}$ & $\begin{array}{l}\text { "Regarding citizen involvement, it is important to incorporate the } \\
\text { perspective of local studies when planning and implementing } \\
\text { adaptation provisions in which the community will take the initiative." } \\
\text { "I hope environmental education will encourage children to pass on } \\
\text { information to adults." }\end{array}$ \\
\hline $2-6$ & $\begin{array}{l}\text { Role of adaptation } \\
\text { provisions }\end{array}$ & $\begin{array}{l}\text { "If they have legal standing, things will probably proceed smoothly." } \\
\text { "Forecast information will be necessary when plans are reviewed; } \\
\text { however, owing to the legal standing, the national government has a } \\
\text { responsibility to provide regularly updated data sets. A framework for } \\
\text { this is required." }\end{array}$ \\
\hline $2-7$ & $\begin{array}{c}\text { Disaster preparation } \\
\text { measures }\end{array}$ & $\begin{array}{l}\text { "Specific disaster preparations cannot be included in the finances of } \\
\text { town, city, and prefectural governments without a system for } \\
\text { evaluating whether the up-front social costs help to avoid risks and } \\
\text { damage." "The priority for allocating financial and human resources } \\
\text { should be considered by keeping long-term projection data in mind." }\end{array}$ \\
\hline $2-8$ & Budgetary allocation & $\begin{array}{l}\text { "The allocation of funds to projects is the job of municipal governments } \\
\text { and should be considered as a community." "Each department has its } \\
\text { own perspective on how to allocate financial and human resources to } \\
\text { important policies, which makes things difficult for adaptation } \\
\text { provisions in areas that environmental departments want to } \\
\text { emphasize." }\end{array}$ \\
\hline $2-9$ & $\begin{array}{l}\text { Impact assessment } \\
\text { technology }\end{array}$ & $\begin{array}{l}\text { "I felt it was necessary to assess the impacts on the prefecture, as well as } \\
\text { animals and plants with small habitats, which got me interested in how } \\
\text { to improve technological accuracy through downscaling." }\end{array}$ \\
\hline $2-10$ & $\begin{array}{l}\text { Using scientific } \\
\text { information }\end{array}$ & $\begin{array}{l}\text { "I do not think that related departments would know how to use } \\
\text { information on precipitation forecasts even if they had it." "Even if } \\
\text { municipalities get information, they cannot digest it, which makes it } \\
\text { challenging to determine ways to convey and use it." }\end{array}$ \\
\hline $2-11$ & $\begin{array}{l}\text { Impact assessment } \\
\text { information needs }\end{array}$ & $\begin{array}{l}\text { "In the field of agriculture, the spatial resolution and information } \\
\text { required differ depending on the field or index. Sometimes, providing } \\
\text { rough results for an area based on forecasts covering a fairly large area } \\
\text { is more useful than detailed forecasts with high spatial resolution." }\end{array}$ \\
\hline
\end{tabular}


Table 5. Themes discussed in WS at the third municipal adaptation forums.

\begin{tabular}{|c|c|c|}
\hline Label & Themes & Example Statements \\
\hline $3-1$ & $\begin{array}{l}\text { Working with } \\
\text { stakeholders }\end{array}$ & $\begin{array}{l}\text { "Because locals are familiar with the area, we need to establish } \\
\text { institutions with personnel, consultants, and other staff that can } \\
\text { generate scientific findings for each area." "It is not only mayors with } \\
\text { fixed terms who have important roles, but also the assembly members } \\
\text { who hold the decision-making power. We need to foster assembly } \\
\text { members who understand the need for adaptation and think about the } \\
\text { future of their communities." }\end{array}$ \\
\hline $3-2$ & $\begin{array}{l}\text { Establishing local } \\
\text { adaptation centers }\end{array}$ & $\begin{array}{l}\text { "It is difficult to secure personnel and funding for establishing local } \\
\text { adaptation centers." "At existing local environmental research institutes } \\
\text { and local universities, there are often mismatches between the } \\
\text { institution's research objectives and its role, which makes collaboration } \\
\text { difficult." }\end{array}$ \\
\hline $3-3$ & $\begin{array}{l}\text { Information required for } \\
\text { formulating an } \\
\text { adaptation plan }\end{array}$ & $\begin{array}{l}\text { "It would be nice to have rough impact forecasts and assessment } \\
\text { datasets to refer to when considering adaptation plans." "When } \\
\text { considering specific adaptation provisions and budgetary allocations } \\
\text { based on forecasts and impact projections, outside expert advice and } \\
\text { funding is needed." }\end{array}$ \\
\hline $3-4$ & $\begin{array}{l}\text { Communicating } \\
\text { scientific data }\end{array}$ & $\begin{array}{l}\text { "Basic data is collected in A-PLAT. The support municipal governments } \\
\text { need and the support that can be provided by the national government } \\
\text { and research institutes need to be discussed." "Reliability varies } \\
\text { depending on the model and resolution; thus, the data provider must } \\
\text { evaluate its reliability before giving it to the user." }\end{array}$ \\
\hline $3-5$ & $\begin{array}{c}\text { Impacts and damages } \\
\text { that appear }\end{array}$ & $\begin{array}{l}\text { "The number of people brought to hospitals due to heat stroke is } \\
\text { growing at the worst pace ever." "Floods and landslides due to intense } \\
\text { and heavy rain are occurring frequently." "I am worried about the } \\
\text { effects of rising temperatures on areas with an increasing number of } \\
\text { immature rice grains." }\end{array}$ \\
\hline $3-6$ & $\begin{array}{l}\text { Studying adaptation } \\
\text { provisions to address } \\
\text { impacts }\end{array}$ & $\begin{array}{l}\text { "It is difficult for municipal governments to consider specific adaptation } \\
\text { provisions based on information on the effects of rising temperatures } \\
\text { due to climate change. Therefore, we would like suggestions on which } \\
\text { adaptation provisions we should undertake." "For example, if } \\
\text { temperature forecasts were provided before rice planting, we could } \\
\text { implement long-term adaptation provisions, such as cross-breeding, } \\
\text { and take other actions, such as planting heat-resistant varieties." }\end{array}$ \\
\hline $3-7$ & $\begin{array}{l}\text { Explanations to other } \\
\text { departments and citizens }\end{array}$ & $\begin{array}{l}\text { "The WBGT heat index is expressed in degrees, the same as } \\
\text { temperature, but because they have different meanings, it is easy to get } \\
\text { confused. It would be good to have an easy-to-understand index for } \\
\text { explanations to citizens and related governmental departments." "What } \\
\text { data are the most effective to help citizens, businesses, and relevant } \\
\text { governmental departments understand the concept of adaptation?" }\end{array}$ \\
\hline $3-8$ & $\begin{array}{l}\text { Local adaptation } \\
\text { consortium projects }\end{array}$ & $\begin{array}{l}\text { "Local adaptation consortium projects are conducted to understand and } \\
\text { survey the needs of municipalities that are attempting to formulate } \\
\text { adaptation provisions." "We are creating a manual for formulating an } \\
\text { adaptation plan as a form of technical support." }\end{array}$ \\
\hline $3-9$ & $\begin{array}{l}\text { Providing impact } \\
\text { assessment information }\end{array}$ & $\begin{array}{l}\text { "Information on whether risks are likely to increase with rising } \\
\text { temperatures and impact assessments from an economic perspective } \\
\text { can be used when ranking priorities and allocating funds based on the } \\
\text { severity and urgency of risks. This type of information is persuasive } \\
\text { when making budgetary requests." }\end{array}$ \\
\hline
\end{tabular}


Table 6. Themes discussed in WS at the fourth municipal adaptation forums.

\begin{tabular}{|c|c|c|}
\hline Label & Themes & Example Statements \\
\hline $4-1$ & $\begin{array}{l}\text { Managing the progress of } \\
\text { adaptation plans }\end{array}$ & $\begin{array}{l}\text { "In the fields of heat and disaster preparation, we are trying to } \\
\text { determine if it is possible to create indices from reference values on the } \\
\text { number of incidents and other factors." "It seems better to set goals and } \\
\text { manage progress based on, for instance, whether society is generally } \\
\text { moving in the desired direction, instead of specific policies and } \\
\text { projects." }\end{array}$ \\
\hline $4-2$ & Deciding priorities & $\begin{array}{l}\text { "In a company, the president makes the final decision on budgets and } \\
\text { priorities, but in municipalities, it can be difficult to set priorities } \\
\text { because the environment department, which is in charge of adaptation } \\
\text { provisions, does not have executive jurisdiction." }\end{array}$ \\
\hline $4-3$ & $\begin{array}{l}\text { Evaluating impact } \\
\text { forecast information }\end{array}$ & $\begin{array}{l}\text { "We want to use indices to express how adapting to climate change will } \\
\text { reduce vulnerability, such as by reducing the amount of damage caused } \\
\text { by disasters." "Important indicators are often not monitored or only } \\
\text { recorded on paper, but monitoring is important because it is necessary } \\
\text { for impact forecasts and assessments." }\end{array}$ \\
\hline $4-4$ & Promoting adaptation & $\begin{array}{l}\text { "There is a debate over whether adaptation, SDGs, and efforts to } \\
\text { improve national resilience have common goals, and whether they can } \\
\text { share frameworks and indices." "It might be good to consider the effects } \\
\text { of global warming and the effectiveness of mitigation and adaptation } \\
\text { provisions within the context of population decline, socioeconomic } \\
\text { changes, and other factors." }\end{array}$ \\
\hline $4-6$ & Interagency coordination & $\begin{array}{l}\text { "In some departments, the concept of adaptation has not been } \\
\text { introduced, and the needs of municipal governments are still } \\
\text { ambiguous." "Some degree of decision-making by leadership is } \\
\text { necessary when using information that contains uncertainty to } \\
\text { formulate adaptation provisions." }\end{array}$ \\
\hline $4-7$ & $\begin{array}{l}\text { Reflecting scientific } \\
\text { information in policy }\end{array}$ & $\begin{array}{l}\text { "Methodologies for including scientific knowledge that contains } \\
\text { uncertainty in policy as evidence have not been established. There } \\
\text { seems to be a gap between the scientific and administrative aspects." }\end{array}$ \\
\hline $4-8$ & $\begin{array}{l}\text { Functions of local } \\
\text { adaptation centers }\end{array}$ & $\begin{array}{l}\text { "Our hope is that after acquiring the basic knowledge to understand } \\
\text { scientific findings, the centers can function as hubs to share information } \\
\text { and scientific findings and communicate closely with the NIES Center } \\
\text { for Climate Change Adaptation." "Local adaptation centers could } \\
\text { mediate between the national and local levels and analyze local } \\
\text { knowledge and information." }\end{array}$ \\
\hline $4-9$ & $\begin{array}{l}\text { Roles of the national } \\
\text { government and NIES }\end{array}$ & $\begin{array}{l}\text { "The role of the NIES Center for Climate Change Adaptation is to guide } \\
\text { and coordinate to ensure that technologies are matched with local needs } \\
\text { and authorize scientific findings." "Information on impacts that affect } \\
\text { the entire country should be provided collectively. Schemes that can be } \\
\text { used for analysis should be created." }\end{array}$ \\
\hline $4-10$ & $\begin{array}{l}\text { Study of local } \\
\text { characteristics }\end{array}$ & $\begin{array}{l}\text { "While adaptation plans should be formulated based on local } \\
\text { characteristics, in some cases the same provision can be applied to } \\
\text { different areas. In the impacts on rice, for instance, introducing } \\
\text { heat-resistant varieties to address the appearance of immature grains } \\
\text { can be implemented similarly in multiple regions. It would be very } \\
\text { difficult to create an adaptation plan with unique adaptation } \\
\text { provisions." "Mostly, impact results that are the same around the } \\
\text { country can be used, while specialty products and rare species will need } \\
\text { surveys or analyses that are customized to local conditions." }\end{array}$ \\
\hline
\end{tabular}

Specifically, the analysis was performed by applying text mining to the transcripts of the WSs on "adaptation planning in general" in the third and fourth municipal adaptation forums. Similar to Tables 3 and 4 for the first and second forums, the themes that were discussed were identified based on the co-occurrences of words and the specifics of each theme were determined by referring to the 
places in the transcripts where keywords related to the theme appeared. As mentioned above, groups were formed at the municipal adaptation forums on "adaptation planning in general," "agriculture," "disaster preparation," and "heat"; however, because this study aimed to analyze the process of adaptation plan formulation, we only examined the discussions in the "adaptation planning in general" WS. Next, the identified themes were organized according to their corresponding steps in the adaptation plan formulation process. This was used to examine how the discussion contents varied for each forum and extract issues associated with each step.

TinyTextMiner (ttm) [12], free software which had been developed by Japanese scientists was used for morphological analysis and R [13] was used for multivariate analysis.

\subsection{Data Preprocessing}

In the analysis, the following preprocessing procedure was performed on transcripts in which information about the speakers was attached to statements extracted from word-for-word transcriptions of voice recordings from the WS discussions. During the WS, facilitators were assigned to intervene minimally to help advance the discussions. Statements by these facilitators were excluded from the analysis.

1. The transcripts of the subject groups were cleaned to unify variations in the expressions and fix other issues to create text files. One comment by one person was considered as one aggregation unit (paragraph), which was tagged with the attributes of the speaker. In the text data used for this study, because speakers expressed themselves in different ways-some speaking simply, others being long-winded, etc.-we determined the presence or absence of words in each statement (paragraph) instead of counting their frequency.

2. Nouns that appeared five or more times were extracted and classified into general nouns and verbal nouns, compound nouns, proper nouns, and adjectival nouns using the ttm part-of-speech system. Words not directly related to the content of the discussion, such as "talk" and "please," were excluded from the analysis.

The above process selected 76 and 86 words from the third and fourth forums, respectively.

\subsection{Identification of Themes Discussed}

In this study, the following procedure was used on the words selected via preprocessing to identify the discussed themes.

1. The occurrence or non-occurrence of subject words was determined for each statement, and a matrix of all statements $\times$ subject words (occurrence: 1 , non-occurrence: 0 ) was created.

2. Principal component analysis was performed on this matrix to determine the principal-component loadings.

3. Hierarchical cluster analysis was performed based on these principal component loadings to classify the subject words. The distance between clusters was defined as the Euclidean distance, and the Ward method was used to calculate the distance. The number of clusters for which interpretable results were obtained was nine and 10, respectively.

4. Next, the word groups classified under each cluster were considered keywords that expressed the content of the discussion of a certain theme, which was used to name the theme.

By referring to the statements containing the keywords classified under the themes identified using the above procedure, the content was organized to understand the specifics of each theme. For the fourth forum, a theme could not be identified for one of the ten clusters; therefore, the subsequent analysis used only nine clusters. 


\subsection{Mapping onto the Guidelines}

Next, the themes identified as having been discussed in the WSs of the first to fourth forums (42 themes in total for the four forums) were organized according to which of the eight steps in the "adaptation plan formulation flow" in the aforementioned Ministry of the Environment guidelines they fell under. Finally, we examined how the topics varied in each forum and attempted to extract the challenges faced by municipal officials at each step.

\section{Results and Discussion}

\subsection{Identification of Themes Discussed}

First, the subject words from the third and fourth forums were classified into clusters to identify the themes that were discussed. The results are presented in Tables 5 and 6 . As the table shows, nine themes were identified for each forum.

\subsection{Mapping onto the Guidelines}

Next, the themes discussed in the WSs at the first to fourth municipal adaptation forums were mapped onto the adaptation plan formulation flow created by the Ministry of the Environment. The results of this are shown in Figure 1. In the figure, the topics discussed in the first to fourth forums are shown in white, light gray, dark gray, and black, respectively. Further, themes that appear under multiple steps are underlined.

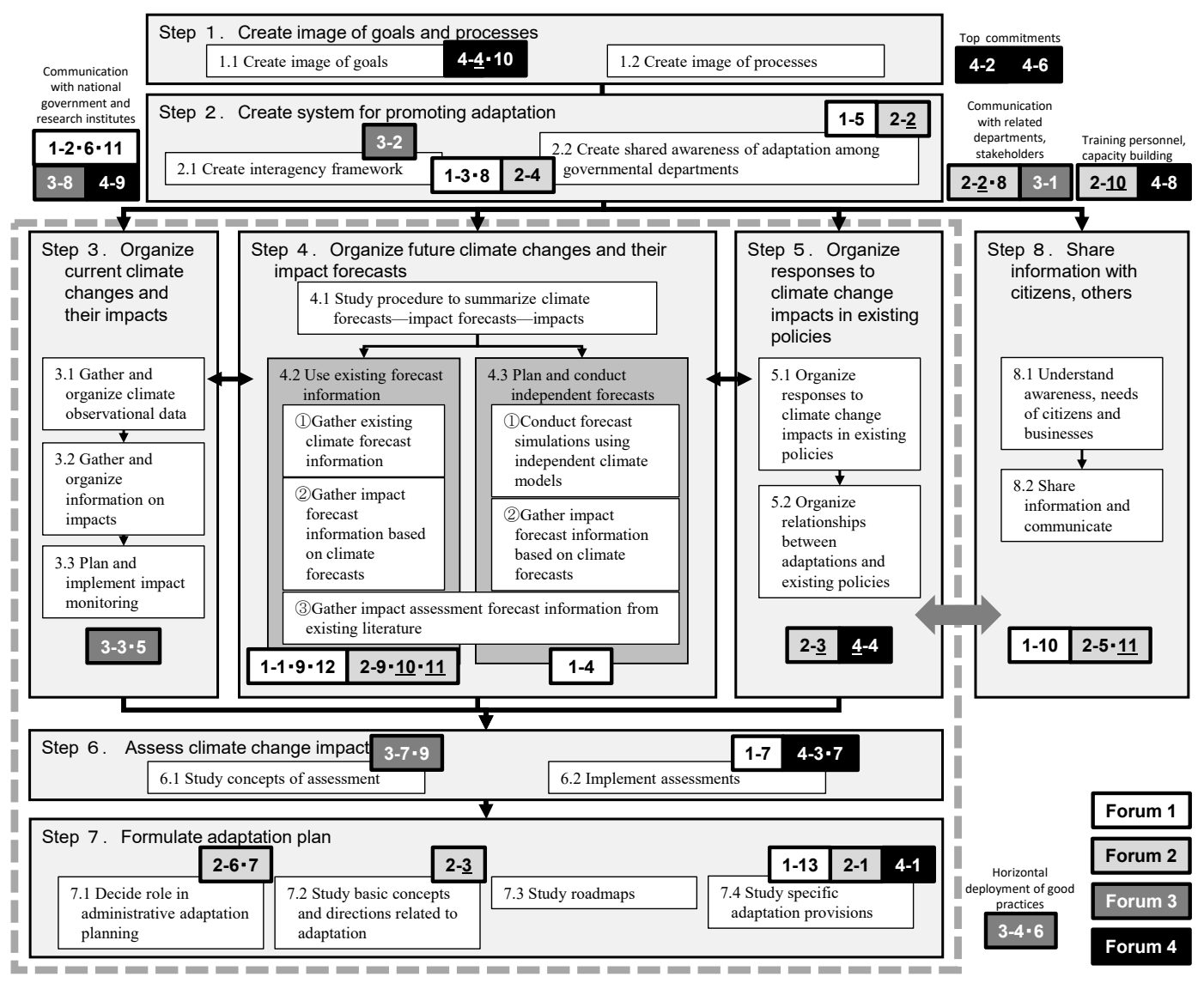

Figure 1. Correspondences between adaptation plan formulation steps and themes discussed in the WSs. The authors added theme labels to the adaptation plan formulation flow from the guidelines [2]. Themes that appear under multiple steps are underlined. 
As demonstrated in the figure, the steps with many associated themes were "Step 2: Create a system for promoting adaptation," "Step 4: Organize future climate change and their impact forecasts," "Step 6: Assess climate change impacts," and "Step 7: Formulate an adaptation plan." Each of these steps contained themes from at least three of the forums. Further, many themes from forums 1-4 were classified under steps 2 and 4, steps 4 and 7, steps 3 and 6, and steps 1 and 6, respectively. This shows that the discussions changed broadly from "Step 2: Create a system for promoting adaptation" to "Step 6: Assess climate change impacts" and "Step 7: Formulate an adaptation plan" in each forum. Significant discussions were held in all forums on "Step 2: Create a system for promoting adaptation," "Step 6: Assess climate change impacts," and "Step 7: Formulate an adaptation plan." The changes in the topics that were discussed are thought to be due to the changes in social conditions, such as the enactment of the Climate Change Adaptation Law and the progress made by municipalities in their initiatives; however, it is clear that impact assessments, which were continually a topic of discussion, are at the core of adaptation plan formulation.

\section{- $\quad$ Step 1: Create image of goals and processes}

Observing the themes classified under each step in the formulation flow, the themes associated with step 1 were "4-4: Promoting adaptation" and "4-10: Study of local characteristics." These themes were discussed in the fourth forum, where the discussion addressed adaptation planning in general, including the formulation of plans based on local characteristics, SDGs, and national land reinforcements, the role of adaptation provisions in other administrative issues, and who decides the ultimate direction.

\section{- $\quad$ Step 2: Create system for promoting adaptation}

The themes associated with step 2 were "1-3: Mainstream adaptation," "1-8: Personnel changes and collaborating with other departments," and "2-4: Revising plans," and there were mentions of creating governmental structures, as in "3-2: Establishing local adaptation centers," and creating a shared understanding relevant departments, as in "1-5: Explanations to other departments" and "2-2: Countermeasures for global warming." Themes related to coordinating and sharing information with other departments were discussed continuously in the first to fourth forums. We surmise that, because knowledge and information are not passed on when staff are transferred and the concept of adaptation has not been introduced, the departments involved created systems for cooperation with time owing to the need for easy-to-understand information and indices to explain the results of impact assessments. These included organizing interdepartmental study groups and devising methods of packaging policies. In the third forum, the requirements of the adaptation law were discussed as in "3-2: Establishing local adaptation centers" and new challenges, such as working with research institutes and securing personnel and funding, were discussed in detail.

\section{- $\quad$ Step 3: Organize current climate changes and their impacts}

The themes associated with step 3 were "3-3: Information needed for formulating an adaptation plan" and "3-5: Impacts and damages that appear." In the second and fourth forums, there was some discussion on the lack of past monitoring data required to formulate adaptation provisions and the challenges involved in implementing continuous monitoring systems.

- Step 4: Organize future climate changes and their impact forecasts

Step 4.2 was associated with six themes on using existing forecast information as in "1-1: Accuracy of research results," "1-9: Need for accuracy," "1-12: Necessary forecast information," "2-9: Impact assessment technology," "2-10: Using scientific information," "2-11: Impact assessment information needs," and Step 4.3, a theme on planning and implementing independent forecasts, as in "1-4: Simple tools." In the first forum, there were discussions on the impact forecasts required to formulate 
adaptation plans and the spatial resolution of these forecasts; however, in the second forum, the discussions became more specific, such as the level of detail needed in agriculture, methods for forecasts based on regional characteristics (i.e., natural ecosystems) and how related departments may not know how to use the forecast information provided by experts. However, the presence of only one theme related to the planning and implementation of independent forecasts suggests that few municipalities are considering conducting their own impact forecasts.

- Step 5: Organize responses to climate change impacts in existing policies

The themes associated with step 5 were "2-3: Examining the contents of plans" and "4-4: Promoting adaptation." Specifically, participants described how even when disaster preparation, agriculture, and other related departments are asked about adaptation provisions, their lack of awareness of these provisions makes it difficult to obtain understanding and cooperation. Other statements were related to step 1, with participants stating that instead of thinking about provisions on their own, municipalities should use the same goals as SDGs and national resilience efforts. Finally, some participants thought that placing adaptation provisions within the context of other administrative issues would facilitate the progress.

- Step 6: Assess climate change impacts

The themes associated with step 6.1 were related to examining the concept of assessments as in "3-7: Explanations to other departments and citizens" and "3-9: Providing impact assessment information" and Step 6.2 related to performing assessments in "1-7: Reviewing priorities," "4-3: Evaluating impact forecast information," and "4-7: Reflecting scientific information in policy." In Step 6.1, while examining the concept of assessments, participants discussed the specifics of formulating adaptation provisions, such as the need for assessments based on easy-to-understand indices, and how information on impact assessments with an economic perspective can be used when making decisions on budgetary allocations and is persuasive when making budgetary requests. In Step 6.2, while performing assessments, in addition to discussing assessment methods with respect to managing the progress of plans and how to reflect scientific findings in the plans, participants also described the importance of monitoring and observational data related to step 3.

- Step 7: Formulate adaptation plan

The themes associated with step 7.1 were related to the role in administrative plans as in "2-6: Role of adaptation provisions," "2-7: Disaster prevention measures," Step 7.2-the consideration of concepts and directions as in "2-3: Examining the contents of plans," Step 7.4-the examination of the specifics of adaptation provisions as in "1-13: Studying specific adaptation provisions," "2-1: Setting numerical goals," and "4-1: Managing progress of adaptation plans." Regarding "2-6: Role of adaptation provisions," when the second forum was held in 2017, adaptation provisions had no legal standing, which meant it was difficult to obtain the understanding and cooperation of related departments. It is expected that the enforcement of the Climate Change Adaptation Law in December 2018 will lead to significant progress and increased "1-3: Mainstream adaptation" in step 2. When Step 7.4 examining adaptation provisions in the second forum, participants described the difficulty of setting numerical goals in adaptation plans and discussed how to package the projects of related departments most effectively. In the fourth forum, in contrast, participants gave specific ideas on creating standardized indices that consider changes in temperature and the number of incidents along with how to measure the progress toward the future society desired by each region.

- Step 8: Share information with citizens, others

Finally, the themes associated with step 8 were "1-10: Easy-to-understand information and reliability," "2-5: Providing information to citizens," and "2-11: Impact assessment information needs." In the 
first forum, participants discussed the need for accurate and understandable information, while in the second forum the focus was on the importance of local leadership in making provisions feel like something personal and involving stakeholders, as well as on the value of environmental education. In all four forums, participants described the need for easy-to-understand information when giving explanations to citizens and related departments. Participants discussed factors such as certainty levels and differing scenarios. Researchers from technological development organizations asked the type of information that was considered easy to understand, though the participants did not come up with a clear image or common set of specifics.

- Themes not classified under any step

The above sections described how the themes discussed in the WSs corresponded with each step in the guidelines. However, several themes were not specifically described in the guidelines. First, the themes associated with step 1 that were related to top commitments, as in "4-2: Deciding priorities" and "4-6: Interagency coordination." It was pointed out that while some level of executive decision-making is necessary when using information that contains uncertainty and making final policy decisions, the adaptation provisions are overseen by environmental departments that do not have executive jurisdiction, which is likely a factor in why it is difficult to determine the priorities.

Next, associated with step 2 are themes related to communication with related departments and stakeholders, as in "2-2: Global warming countermeasures," "2-8: Budgetary allocation," and "3-1: Working with stakeholders." In the second forum, participants described the challenges involved in raising awareness by providing information to related departments and the general public, and determining the coordination and allocation of funds among departments involved in adaptation provisions, spanning a wide variety of fields. In the third forum, participants described their expectations regarding the roles of local universities, research institutes, and consultants in formulating adaptation plans and establishing local adaptation centers, and expressed opinions on the importance of directors and assembly members in promoting adaptation provisions. There were also themes related to human resource development and capacity building, as in "2-10: Using scientific information" and "4-8 Functions of local adaptation centers." The roles and functions of local adaptation centers were discussed in the third forum in relation to step 2, and while these topics had become clearer by the fourth forum, we surmise there are still unresolved issues related to the institutions that carry out the centers' roles and secure personnel.

Further, associated with steps 4 and 7 were themes related to communication with the national government and research institutes, as in "1-2: Data sources," "1-6: National government authorization," "1-11: Top-down information," "3-8: Local adaptation consortium projects," "4-9: Roles of the national government and NIES," "3-4: Communicating scientific data," and "3-6: Studying adaptation provisions to address impacts." In the first forum, participants discussed how, in addition to having reliable information, they wanted impact forecast data authorized by the national government, such as that published by national institutes, and to be provided with impact assessment items in a top-down manner. By the third forum, although participants could obtain basic information from A-PLAT and other sources, they said it was difficult for municipalities on their own to understand and formulate countermeasures to address increasing risk levels based on the results of impact assessments and other data. Participants discussed the need for information including adaptation provisions, the horizontal deployment of good practices, personnel and frameworks to assist in using impact assessment information, and assessment information from an economic perspective, related to "Step 6: Evaluating climate change impacts." Gradually, the topics of discussion changed from vague issues, such as the sources and reliability of information, to how to use and deploy information and use it when considering adaptation provisions, which indicates that the discussions became intense.

Although the guidelines established by the Ministry of the Environment contain specific task elements and procedures for each step, they are quite abstract in comparison to the discussions in the WSs. Because specific methods for each step are not described in detail, staff in charge have 
difficulty making progress in their work based on an understanding of the steps. For example, many municipalities are aware of the challenges involved in prioritizing countermeasures and studying specific countermeasures for anticipated impacts. For the former, although the guidelines provide three perspectives for making assessments—significance, urgency, and confidence-participants emphasized the need for economic assessments, suggesting that the assessments based on these three perspectives are insufficient. For the latter, no directions or concepts have been provided for considering concrete measures, such as whether to reinforce existing measures or formulate new ones. In addition, as stated above, the steps imply nothing about considering the priority of projects or budgetary allocation. Further, communication with the national government, research institutes, related departments, and stakeholders, along with human resource development and capacity building were mentioned in all four forums. While many municipalities consider these to be challenges in promoting adaptation provisions, the guidelines have a closed structure that focuses on the municipality's formulation of a plan. No mention is made of the roles that other institutions or related stakeholders should play or how to cooperate with them as preconditions for formulating a plan. This indicates a need to clarify the roles and functions of the national government, regional adaptation centers, municipalities, and other related institutions while also providing the ability to coordinate these various entities to a particular institution. As mentioned earlier, it is expected that many local governments will use existing impact assessments instead of implementing them independently, but some seek advice and assistance when collecting and utilizing impact assessment information. Therefore, it is considered that the clarification of the organization with the coordination function is an urgent issue. In addition, it is necessary to discuss what information is easy to understand for each stakeholder.

\section{Conclusions}

This study incorporated themes discussed in WSs held for experts (on areas such as climate models and impact assessments), researchers from local environmental institutes, and municipal officials and organized them under their corresponding steps in the adaptation plan formulation process. We attempted to understand how the discussions changed with time and extracted issues related to the formulation process. The results showed that, in the first to fourth forums, discussions in the WSs varied between creating adaptation promotion systems, assessing the impacts of climate change, formulating adaptation plans, communicating with related organizations and stakeholders, developing human resources, and capacity building. Specifically, the discussions under step 6, for example, deepened over time, moving from how to determine priorities to the need for assessments from an economic perspective, issues related to monitoring and impact forecasts, and how to reflect scientific knowledge that contains uncertainty in policy. In addition, as described in Section 3.2, after organizing the challenges faced by municipalities in each step of the guidelines and examining the procedures and contents of the guidelines, we found that the guidelines were more abstract than the WS discussions. This indicates a need for information, procedures, content, and assistance that envision the actual work of formulating an adaptation plan. During the WSs, the participants constantly mentioned the difficulties involved in assessing and considering whether to strengthen or formulate new provisions based on the results of impact assessments, which indicates that this issue deserves to be prioritized. In addition, the roles of related organizations and stakeholders and the coordination of communication between them are important topics that need to be discussed.

Despite these findings, the following issues remain. First, the themes dealt with in this study are limited to those identified by implementing text mining in the WS discussions; thus, not all issues and problems associated with each step in adaptation planning have been identified. Moreover, because this study focused on identifying issues related to the process of formulating adaptation plans, we only examined the discussions in the WSs on adaptation planning in general. The consideration and drafting of adaptation provisions across sectors also needs to be examined by integrating the discussions in the WSs on disaster preparation, agriculture, heat, and other fields. 
Author Contributions: Conceptualization, methodology, formal analysis, A.I., T.M., and M.K.; writing一original draft preparation, A.I.; writing-review and editing, T.M. and M.K; supervision, K.B.; project administration, M.T.; funding acquisition, M.T. All authors have read and agreed to the published version of the manuscript.

Funding: This research was funded by the Social Implementation Program on Climate Change Adaptation Technology (SI-CAT) of the Ministry of Education, Culture, Sports, Science and Technology (MEXT).

Acknowledgments: The authors thank all participants in Forums and Japan Weather Association for making transcriptions of WSs.

Conflicts of Interest: The authors declare no conflict of interest.

\section{References}

1. United Nations. The Paris Agreement. Available online: https://unfccc.int/process-and-meetings/the-parisagreement/the-199paris-agreement (accessed on 13 January 2020).

2. Ministry of the Environment Government of Japan. Guidelines on Formulating Climate Change Adaptation 201 Plans for Local Governments. Available online: https://adaptation-platform.nies.go.jp/jichitai/archive/ guideline_H28_08_env.pdf (accessed on 12 January 2020).

3. The National Institute for Environmental Studies. A Climate Change Adaptive Information Platform. Available online: https://adaptation-platform.nies.go.jp/en/index.html (accessed on 14 January 2020).

4. Ministry of the Environment Government of Japan. National Adaptation Plan. Available online: https: //www.env.go.jp/en/earth/cc/adaptation/mat02.pdf (accessed on 14 January 2020).

5. Ministry of Education, Culture, Sports, Science and Technology. Social Implementation Program on Climate Change Adaptation Technology. Available online: https://si-cat.jp/en/ (accessed on 14 January 2020).

6. Van Aalst, M.K.; Cannon, T.; Burton, I. Community level adaptation to climate change: The potential role of participatory community risk assessment. Glob. Environ. Chang. 2008, 18, 165-179. [CrossRef]

7. Carter, J.G. Climate change adaptation in European cities. Rev. Artic. Curr. Opin. Environ. Sustain. 2011, 3, 193-198. [CrossRef]

8. Porter, J.J.; Demeritt, D.; Dessai, S. The right stuff? Informing adaptation to climate change in British Local Government. Glob. Environ. Chang. 2015, 35, 411-422. [CrossRef]

9. Baba, K.; Matsuura, M.; Kudo, T.; Watanabe, S.; Kawakubo, S.; Chujo, A.; Tanaka, H.; Tanaka, M. Climate Change Adaptation Strategies of Local Governments in Japan. Oxf. Res. Encyclopedia Clim. Sci. 2017, 1-27.

10. Iwami, A.; Kimura, M.; Matsui, T.; Baba, K. Visualization of differences between researchers' seeds and local officials' needs about climate change adaptation plan. In Proceedings of the 46 Annual Meeting of Japanese Environment Mutagen Society, Tokyo, Japan, 6-7 November 2017; pp. 287-292. (In Japanese).

11. Iwami, A.; Kimura, M.; Matsui, T.; Baba, K. Identifying local governments' challenges and needs in developing climate change adaptation strategies-Through practice of co-design workshop. Environ. Syst. Res. 2018, 47, 93-101. (In Japanese) [CrossRef]

12. Matsuura, M.; Miura, A. TTM: Tiny Text Miner $\beta$ Version. Available online: http://mtmr.jp/ttm/ (accessed on 12 January 2020).

13. Institute for Statistics and Mathematics. The R Project for Statistical Computing. Available online: http://www.r-project.org/ (accessed on 12 January 2020).

(C) 2020 by the authors. Licensee MDPI, Basel, Switzerland. This article is an open access article distributed under the terms and conditions of the Creative Commons Attribution (CC BY) license (http://creativecommons.org/licenses/by/4.0/). 